\title{
The Effect of Remittances on Imports in Eight Latin-American Countries
}

\author{
JULIO CÉSAR HERNÁNDEZ \\ University of Puerto Rico, Mayagüez Campus* \\ WILFREDO TOLEDO \\ University of Puerto Rico, Río Piedras Campus
}

\begin{abstract}
Remittances are an important source of external resources for developing countries. These transfers may increase the levels of consumption and capital formation in these economies. This paper examines the economic impact of international remittances on different import categories. A panel VAR was estimated using data from eight Latin-American economies during the 1991 to 2004 period. The impulse response functions show that remittances increase imports of capital, consumption, and intermediate goods. It was also found that the accelerator is a plausible transmission mechanism from this type of income to investment.
\end{abstract}

Keywords: Imports, Remittances, Panel VAR, Central America

JEL Classification F16, F24

\section{Introduction}

Remittances by immigrant workers are an important source of funds for many developing countries. These transfers may increase the levels of consumption and investment in these economies. Also, remittances can have an impact on international flows of goods and capital (Dutta and Ahmed, 1999). This paper analyzes the economic effect of global remittance inflows on three import categories for eight Latin American economies described below. It is interesting to determine the effect of remittances on imports for several reasons. On the one hand, imports of consumer and capital goods may be better indicators of consumption and investment than

\footnotetext{
* The authors are grateful to the editor of this journal and an anonymous referee for valuable comments and suggestions. Hernández: Department of Agricultural Economics and Rural Sociology, College of Agricultural Science julio.hernandez3@upr.edu; Toledo: Department of Economics College of Social Science wilfredotoledo@aol.com PO BOX 21758 UPR Station Río Piedras, P.R. 00931. (787)-764-0000- ext. 87516

(C) 2020 Julio César Hernández and Wilfredo Toledo. Licensed under the Creative Commons Attribution - Noncommercial 3.0 Licence (http: / / creativecommons.org/licenses/by-nc/3.0/ . Available at http: //rofea.org.
} 
the variables alone. This is because some capital accumulation may be affected by the level of consumption through the accelerator mechanism. Thus, the impact of remittances on each of these two variables may be isolated. On the other hand, it is informative to determine if some of the remittance income generated in the developed countries are returning to them through imports.

The principal contribution of this paper is twofold. First, it examines the impact of remittance on imports of capital and consumption goods, an issue that has not been the subject of much study. Second, a theoretical model to explain a mechanism of transmission from remittance to investment is constructed. In addition, the model is tested in a sample of countries where this topic has not been deeply analyzed.

This paper uses data for the six Spanish-speaking countries of Central America, as well as Colombia and Venezuela. The last two nations were included because they have strong trade relations with the region of Central America. These eight countries were chosen because there are not many analytical studies about the impact of remittance on them, even though these transfers are a primary source of funds for these economies. In 2004, this type of income represented close to $2 \%$ of the GDP of Costa Rica and Panama, and more than $10 \%$ for Honduras, El Salvador, and Guatemala (Hammill, 2007). This may imply that variability in this income has the potential to impact the state of the economy in these countries, as is pointed out by Hammill (2007).

The data used in the empirical analysis covers the period from 1991 to 2004. The initial year was selected because it was the beginning of a relatively stable period for this area: The civil wars in some nations of Central America had ended, and democracy began in some of them (Hammill, 2007). The last year was chosen to isolate the impact of remittances on imports from the structural changes associated with the Central American Free Trade Agreement (CAFTA). Figure 1 shows the dynamics of the remittances per capita during this period for the Latin American countries examined in this paper. As is evident from this figure, most of the series have a positive long-run trend. However, for some of the countries, these variables exhibit some volatility over time.

To explore in more detail the behavior of this source of income during the period under analysis, some annual descriptive statistics for per capita remittances and the ratio of this variable to GDP are presented in Table 1. As can be seen from the Table, El Salvador and Honduras have the highest level of per capita remittances, while Panama and Venezuela have the lowest values for this variable. On the other hand, the annual average of the ratio of remittances to GDP varies from $11.9 \%$ in El Salvador to $0.1 \%$ in Venezuela. Both series exhibit considerable variability in the period under study as judged by the difference between the lowest and highest values (the range).

Table 2 contains some summary statistics for imports as a percentage of GDP and the proportion of remittance to imports. Imports represent up to $80 \%$ of the Gross Domestic Product 
in Panama. For most of the countries in the sample, this ratio exceeds $33 \%$. One the other hand, the ratio of remittances to imports is $34.9 \%$ in El Salvador, $23.2 \%$ in Colombia, and $15.5 \%$ in Nicaragua. The countries with the lowest values to this proportion are Venezuela and Panama. It is important to point out that the effect of these transfers from migrant workers to their home countries on the sales to the rest of the world may be higher because of the multiplier effects.

Figure 1. Remittances Per Capita for the Countries in the Sample (1990 to 2004)

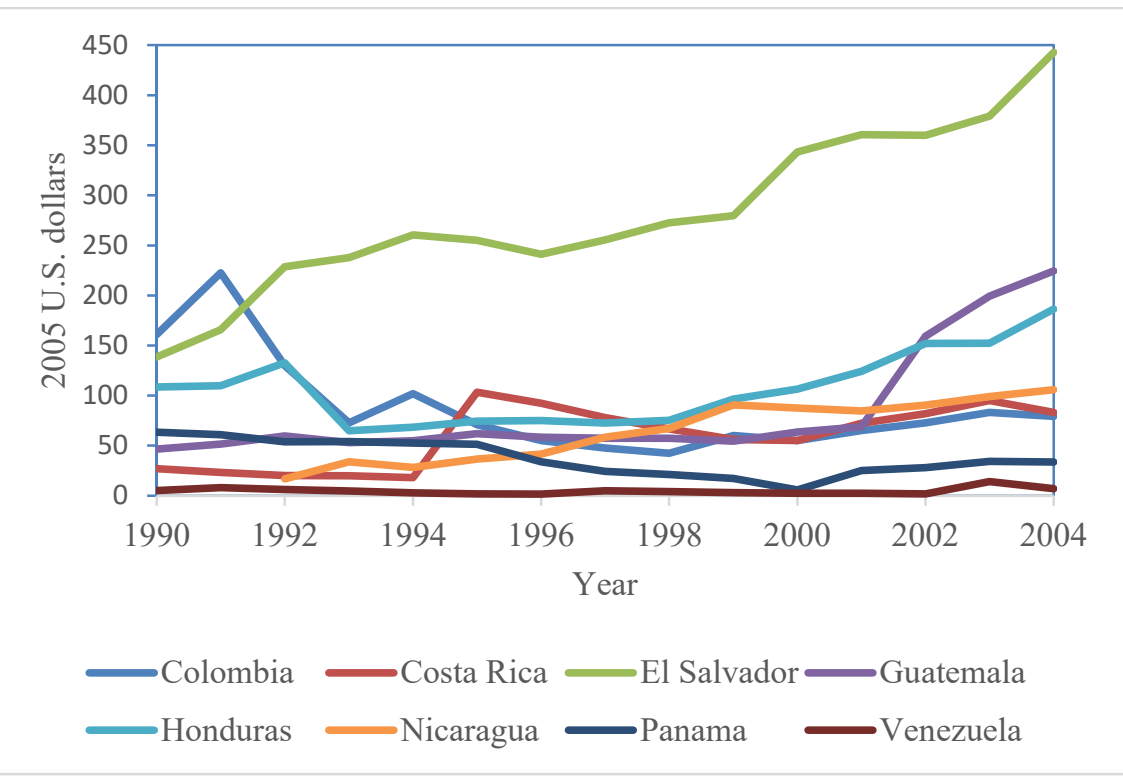

Table 1. Some Descriptive Statistics of Remittances for Eight Countries of Latin America Annual Data from 1990 to 2004 in 2005 USD

\begin{tabular}{|l||l|l|l|l|l|l|}
\hline \multicolumn{1}{|c||}{} & \multicolumn{3}{c|}{ Remittance per capita } & \multicolumn{3}{c|}{ Remittance } \\
\hline Country & Mean & Minimum & Maximum & Mean & Minimum & Maximum \\
\hline Colombia & 87.931 & 42.344 & 222.613 & 0.029 & 0.013 & 0.078 \\
\hline Costa Rica & 59.472 & 17.948 & 103.331 & 0.015 & 0.005 & 0.028 \\
\hline Guatemala & 84.690 & 46.516 & 224.417 & 0.042 & 0.026 & 0.105 \\
\hline Honduras & 106.664 & 64.872 & 186.422 & 0.087 & 0.053 & 0.138 \\
\hline Nicaragua & 64.648 & 16.704 & 105.822 & 0.055 & 0.000 & 0.094 \\
\hline Panama & 37.276 & 5.786 & 63.458 & 0.010 & 0.001 & 0.021 \\
\hline El Salvador & 281.375 & 138.504 & 442.775 & 0.119 & 0.076 & 0.162 \\
\hline Venezuela & 4.619 & 1.604 & 13.998 & 0.001 & 0.000 & 0.003 \\
\hline
\end{tabular}


Table 2 Some Descriptive Statistics of Remittances and Imports for Eight Countries of Latin America Annual Data from 1990 to 2004 in 2005 USD

\begin{tabular}{|l||l|l|l|l|l|l|}
\hline \multicolumn{2}{|c||}{} & \multicolumn{3}{c|}{$\frac{{ }^{2}}{\text { GDP }}$} & \multicolumn{3}{c|}{ Imports } \\
\hline \hline Country & Mean & Minimum & Maximum & Mean & Minimum & Maximum \\
\hline Colombia & 0.156 & 0.085 & 0.191 & 0.232 & 0.073 & 0.911 \\
\hline Costa Rica & 0.462 & 0.362 & 0.555 & 0.032 & 0.011 & 0.064 \\
\hline Guatemala & 0.361 & 0.250 & 0.432 & 0.114 & 0.065 & 0.247 \\
\hline Honduras & 0.678 & 0.626 & 0.793 & 0.127 & 0.081 & 0.174 \\
\hline Nicaragua & 0.374 & 0.220 & 0.493 & 0.155 & 0.068 & 0.207 \\
\hline Panama & 0.804 & 0.626 & 1.157 & 0.012 & 0.002 & 0.024 \\
\hline El Salvador & 0.346 & 0.222 & 0.438 & 0.349 & 0.297 & 0.472 \\
\hline Venezuela & 0.128 & 0.073 & 0.178 & 0.007 & 0.003 & 0.026 \\
\hline
\end{tabular}

\section{Literature Review}

There is ample literature on several aspects of remittances. This section focuses on a sample of the papers that are more related to our study. Amuedo-Dorantes and Pozo (2004), using a panel of thirteen Latin American and Caribbean countries, estimate that a percentage point increase in the remittances to GDP ratio leads to a real exchange rate appreciation of about $22 \%$. Additional evidence for this relationship is provided by Lopez, Molina, and Bussolo (2007) for a panel data of twenty countries of Latin America and the Caribbean. Their estimations show that a percentage point increase in the remittances to GDP ratio would increase the real exchange rate by about $2.5 \%$. This change in terms of trade may imply a loss in international competitiveness and an inauspicious scenario for the domestic producers.

The cyclical dynamics of remittances are examined by Chami, Fullenkamp, and Jahjah (2003) using a panel data set of 113 countries in 29 years. Their analysis shows that remittances have a countercyclical behavior and consequently do not seem to be a significant source for capital acquisition that promotes economic growth. They also contend that the lion's share of remittances is spent on consumption with the residual portion being allocated towards savings or investments.

For the case of Mexico, Taylor and Mora (2006) analyzed the effect of remittance on household consumption, using a cross-sectional data set of 2003. The authors found that households receiving migrant remittances spend proportionally less on food relative to those that do not receive them. Furthermore, they found that households receiving remittances invest more compared to those that do not. The results of the estimation undertaken by the authors 
show that households receiving remittances consume fewer education services than those that do not have this type of income. In the same line, Castaldo and Reilly (2007), using crosssection data for Albania, examined the effect of remittances on the expenditure of four commodity categories: food, non-food, durable goods, and utilities. They found that remittances exhibit a significant positive effect on consumers' purchases of three types of goods: food, durables, and utilities. These findings are in contrast with the results reported by Adams (2005). This author, employing Guatemalan data, found that international remittance flow to households decreases their propensity to consume food.

The relationship between remittances and investment in human capital is analyzed by Edwards and Ureta (2003), using cross-sectional data for households in El Salvador. The results of the estimations suggest that remittances have a more significant effect on school retention rates than income from all other sources. Further investigations found that remittances may reduce poverty and income inequality in developing economies (Adams and Page, 2005; Stark et al., 1986; Taylor, 1992).

Other studies like Arize and Osang (2007) and Dutta and Ahmed (1999) examine how the import's demand is affected by variables like GDP growth (or income), import price, and real foreign reserves. Arize and Osang (2007) explore the relationship between import demands in Latin American countries. The data for this study comes from countries like Argentina, Brazil, Colombia, Costa Rica, Ecuador, Trinidad, and Venezuela. The authors found evidence that income and foreign exchange reserves have positive and significant effects on all countries'" imports. On the other hand, an aggregate import demand function estimation for Bangladesh is presented by Dutta and Ahmed (1999). These authors, using data from 1974 to 1994, found that the import demand has a significant and negative relationship with prices, but a positive one with gross domestic product and exchange reserves. Dutta and Ahmed point out that remittances of nationals working abroad are one of the principal sources of exchange reserves.

\section{A General Theoretical Framework}

Consider an economy with two sectors: consumption and production. In each sector, agents maximize their objective functions. The consumer may buy three types of final consumer goods: locals $\left(\mathrm{C}_{\mathrm{LCALG}}\right)$, imported $\left(\mathrm{C}_{\mathrm{IMPG}}\right)$, and locals produced using imported intermediated goods $\left(\mathrm{C}_{\text {IMPINTR }}\right)$. In each period the aggregate consumption is given by equation 1 . Where $\mathrm{C}_{t}$ is total consumption at a point in time $t$, and $\mathrm{C}_{\text {IMPINTR }}$ is a function that transforms intermediate goods in final consumption goods.

$$
C_{t}=C_{L C A L G, t}+C_{I M P G, t}+C_{I M P I N T R, t}
$$


The problem of the household is to choose current consumption expenditure to maximize expected lifetime utility ${ }^{1}$.It is assumed that the maximization of that preference function of a representative consumer generates a consumption path characterized by:

$$
C_{X, t}=\sum_{i=1}^{p} \gamma_{i} C_{X, t-i}
$$

where $C_{X, t}$ is $\mathrm{X}$ type of consumption at time $t ; X=L C A L G, I M P G$, or IMPINTR, and the $\gamma_{\mathrm{i}}$ are parameters.

The habit persistence consumption theory is the justification for equation (2). Consumers with a habit formation utility function will delay some of their response to income shocks, smoothing changes in consumption. The countries included in the sample are middle and lowincome. Thus, a significant proportion of the population may have a subsistence level of consumption. Hence, this variable should be stable through time, and the habit preference consumer model seems to be adequate ${ }^{2}$.

In the production sector, there is an unlimited labor input, but capital goods are scarce. Two classes of capital goods $(\mathrm{K})$ are available: local capital $\left(K_{L C A L}\right)$ and imported capital $\left(\mathrm{K}_{\mathrm{IMPC}}\right)$. Therefore, capital stocks and investment $\left(\mathrm{I}_{\mathrm{t}}\right)$ are given by:

$$
K=K_{L C A L}+K_{I M P C} \text { and } I_{t}=\left(K_{t}-K_{t-1}\right)+\delta K_{t-1}
$$

It is assumed that producers are confronted with the problem of choosing the investment expenditures to minimize the expected flow of discounted $\operatorname{costs}^{3}$. This type of problem leads to the following investment function:

$$
I_{z, t}=\sum_{i=1}^{q} \emptyset_{i} C_{t-i}+\delta K_{y, t-1} ; 0<\delta<1
$$

where $\mathrm{Z}$ is equal to LCAL or IMPC, the $\varphi$ s are parameters, and $\delta$ is the depreciation rate.

\footnotetext{
${ }^{1}$ Byun (2013) has an exhaustive discussion of the class of utility functions that produce the dynamics for the consumption given by (2).

${ }^{2}$ Individuals in this region have a strong cultural identity that may be reflected in a steady pattern for consumption. Furthermore, in an estimation of an AR(1) process for real consumption in the data set, it was found a coefficient of 0.94 for the lagged dependent variable. This reveals a considerable persistence of this variable in the sample. A graphical analysis revealed a fairly smooth long-run trend in the consumption series of all countries included in the estimation, except by Venezuela, where this variable exhibits high volatility during the period examined. Thus, the habit persistence theory seems to be a reasonable hypothesis for the estimation using the panel data set but may not be a good description of the consumption patterns of this last country.

${ }^{3}$ Abel and Blanchard (1988) discuss this type of objective function.
} 
In equation (3), investment is represented as a function of lags of consumption and one lag of capital stock. Thus, investment is described as the flexible accelerator model. This theory seems to be plausible for small, underdeveloped countries such as the ones analyzed here, which have capital limitations. It is probable that positive shocks in consumption, as those stimulated by remittances, lead to new investment.

The resources constraint in each period may be expressed as equation 4 .

$$
Y_{t}+R_{t} \geq C_{t}+I_{t}
$$

where $\mathrm{Y}$ is aggregate local production, $\mathrm{R}$ represents workers' remittances, and I represents the sum of the two types of investment.

Equation 4 implies that there is a flow of transfers from abroad (i.e., remittances), and in each period, the decisions about consumption will affect the choice of capital and vice versa (they are jointly determined $)^{4}$.

Therefore, the parameters in equations (2) and (3) may be estimated in a vector autoregressions (VAR) model. The three import series and remittances are included as endogenous variables. Contemporaneous values of consumption and investment were also added as exogenous variables ${ }^{5}$.

\section{Methodology and Preliminary Data Analysis}

The panel data VAR (PVAR) model may be represented as:

$$
Y_{i t}=\Phi(L) Y_{i t}+X_{i t} \mathrm{~B}+\varepsilon_{i t}
$$

where:

$i$ is the index for the country and $t$ for years

$Y_{i t}$ is a $4 \mathrm{x} 1$ vector that contains the logarithms of the endogenous variables: imports of capital goods [Log $\left.\left(I M P C_{i t}\right)\right]$, imports of consumption goods [Log $\left(\mathrm{IMPG}_{\mathrm{it}}\right)$, imports of intermediate goods [Log(IMPINTR $\left.\left.\mathrm{Iit}_{\mathrm{it}}\right)\right]$ and remittances $\left[\log \left(\mathrm{R}_{\mathrm{it}}\right)\right]$

$X_{i t}$ is a matrix of exogenous variables: intercepts, dummies, and other control variables such as consumption, investment, GDP, and exchange rate

$\varepsilon_{\mathrm{it}}$ is a vector of the stochastic elements of the models

\footnotetext{
${ }^{4}$ This result depends on the assumption that remittances affect the consumption of domestic and imported goods uniformly.

${ }^{5}$ In an additional estimation, the GDP was the control variable utilized in the PVAR, but the results do not differ qualitatively and are not presented. The exchange rate was evaluated but was not statistically significant.
} 
$\Phi(L)$ is a matrix of polynomials in the lags operator that contains the parameters of the autoregressive components of the model.

System (5) is a dynamic model that expresses each of the import categories considered here and remittances as a function of their past values and exogenous variables. This modeling strategy implies that decisions about imports are not independent of each other and also depend on external income flows. Resources restrictions justified that conjecture. The model was estimated using an unbalanced panel from eight Latin American countries, as mentioned in the introduction. The data came from the Word Bank Data Base. The LSDV estimator was used because this estimator is consistent when the length of the time series (T) is greater than the cross-section observations $(\mathrm{N})(\mathrm{T}>\mathrm{N})$.

The estimation of system (5) requires stationarity of its variables. To assess that condition unit roots and cointegration tests have to be performed. The results of the Augmented DickeyFuller test reveal that all variables included in the system are I(1). The cointegration test results are informed in Table 3. As is evident from this table, the system contains two cointegration relationships. Thus, a VEC model was estimated.

\section{Estimation Results of a Panel VEC Model}

System (4) may be expressed as an error correction model (VEC) as:

$$
\Delta Y_{i t}=\Pi Y_{i, t-1}+\sum_{i=1}^{k-1} \Gamma_{i} \Delta Y_{i t}+X_{i t} \mathrm{~B}+\varepsilon_{i t}
$$

where: $\Pi$ is a matrix of the coefficients of the endogenous variables. If the system is cointegrated, then $\Pi=\alpha \beta^{\prime}$, with $\alpha$ being a matrix of the parameters that reflects the celerity of the adjustment towards equilibrium and $\beta$ the coefficients of the long-run relationship.

\subsection{Long Run Relationships}

It is known that the cointegration relationship comes from statistical procedures as Johansen methods, so to obtain an economic interpretation it is necessary to impose restrictions on the matrices $\alpha \beta^{\prime}$. Usually, economic theory is used to justify those restrictions. However, one of the objectives of this paper is to compare the impacts of remittances on different classes of imports. Therefore, the econometric specification does not impose that type of restrictions to avoid bias in the evaluations. Consequently, the restrictions were chosen using statistical significance tests and the normalization needed to analyze the issue posed in this paper.

In system (6) two exclusion restrictions were imposed on the $\alpha$ 's and three over the cointegration vector $(\beta)$. Also, the normalization implies that one of the cointegration equation corresponds to capital import goods and the other to the imports of consumptions goods. 
HERNÁNDEZ, TOLEDO Remittances and Imports in Latin America

Table 3 Summary of Cointegration Test Results

\begin{tabular}{|c|c|c|c|c|}
\hline \multicolumn{5}{|c|}{ A. Trace statistics $\left(\lambda_{\text {trace }}\right)$ Test } \\
\hline H0: & \multirow[t]{2}{*}{ Eigenvalue } & \multirow{2}{*}{$\lambda_{\text {trace }}$} & \multirow{2}{*}{$\begin{array}{c}0.05 \\
\text { Critical Value }\end{array}$} & \multirow[t]{2}{*}{ P-Value } \\
\hline No. of CE(s) & & & & \\
\hline $0 *$ & 0.461 & 100.154 & 55.246 & 0.000 \\
\hline At most $1 *$ & 0.243 & 43.265 & 35.011 & 0.005 \\
\hline At most 2 & 0.119 & 17.646 & 18.398 & 0.064 \\
\hline At most $3 *$ & 0.063 & 5.968 & 3.841 & 0.015 \\
\hline \multicolumn{5}{|c|}{ B. Maximum Eigenvalue $\left(\lambda_{\operatorname{MAX}}\right)$ test } \\
\hline H0: & \multirow[t]{2}{*}{ Eigenvalue } & \multirow[t]{2}{*}{$\lambda_{\mathrm{MAX}}$} & \multirow{2}{*}{$\begin{array}{c}0.05 \\
\text { Critical Value }\end{array}$} & \multirow[t]{2}{*}{ P-Value } \\
\hline No. of CE's & & & & \\
\hline $0 *$ & 0.461 & 56.889 & 30.815 & 0.000 \\
\hline At most $1 *$ & 0.243 & 25.619 & 24.252 & 0.033 \\
\hline At most 2 & 0.119 & 11.678 & 17.148 & 0.262 \\
\hline At most $3 *$ & 0.063 & 5.9677 & 3.8415 & 0.015 \\
\hline
\end{tabular}

Trace test indicates two cointegrating equations at the 0.05 level * Denotes rejection of the hypothesis at the 0.05 level

The joint hypothesis that excluded parameters are equal to zero is not rejected using the LRstatistics that has a Chi-square distribution (P-value of 0.15 ). Those restrictions identify both cointegration equations. According to these criteria, the long-run relationships are given by the following:

$$
\left[\begin{array}{l}
\Delta Y 1_{i t} \\
\Delta Y 2_{i t} \\
\Delta Y 3_{i t} \\
\Delta Y 4_{i t}
\end{array}\right]=\left[\begin{array}{cc}
.24 & 0 \\
.64 & -.51 \\
.37 & -.31 \\
0 & .16
\end{array}\right]\left[\begin{array}{cccccc}
1 & 0 & 0 & -1.59 & -13 & .21 \\
0 & 1 & .47 & -2.06 & -16.5 & .26
\end{array}\right]\left[\begin{array}{l}
Y 1_{i, t-1} \\
Y 2_{i, t-1} \\
Y 3_{i, t-1} \\
Y 4_{i, t-1} \\
1 \\
t
\end{array}\right]_{+}\left[\begin{array}{l}
\varepsilon_{1 t} \\
\varepsilon_{2 t} \\
\varepsilon_{3 t} \\
\varepsilon_{4 t}
\end{array}\right]
$$

where $\mathrm{Y} 1$ is the $\log \left(\mathrm{IMPC}_{\mathrm{it}}\right), \mathrm{Y} 2$ is the $\log \left(\mathrm{IMPG}_{\mathrm{it}}\right), \mathrm{Y} 3$ is the $\log \left(\mathrm{IMPINTR}_{\mathrm{it}}\right)$, and $\mathrm{Y} 4$ is the $\log \left(\mathrm{R}_{\mathrm{it}}\right)$.

The long run relationships can also be expressed in equation forms as follows:

$$
\log \left(I M P G_{i t}\right)=16.58-.26 t+0.46 \log (I M P I N T R)+2.06 \log \left(R E M_{i t}\right)+\varepsilon_{G, i t}
$$

All of the estimated parameters in (8) statistically differ from zero at the one percent significance level. This implies that in the long-run, remittances are important for the dynamics of imports of capital and consumption goods. However, as can be seen, the elasticity with respect to this type of income is slightly higher for consumption goods than for capital. These 
results are compatible with the claim that the principal use of this flow of income in developing countries is to finance consumption. However, as it was discussed in section 2, remittances may affect capital goods imports via the accelerator principle, too. This point will be discussed in greater detail in the next section.

\subsection{Dynamic Analysis}

To identify the errors terms of the VAR model as structural shocks, the following contemporaneous structure between the residuals was imposed:

$$
\begin{gathered}
\epsilon_{R E M, t}=\mu_{R e m, t} \\
\epsilon_{I M P G, t}=\gamma_{21} \mu_{R, t}+\mu_{I M P G, t} \\
\epsilon_{I M P C, t}=\gamma_{31} \mu_{R, t}+\gamma_{31} \mu_{I M P G, t}+\mu_{I M P C, t} \\
\epsilon_{I M P I N T R, t}=\gamma_{41} \mu_{R, t}+\gamma_{42} \mu_{I M P C, t}+\gamma_{43} \mu_{I M P G, t}+\mu_{I M P I N T R, t}
\end{gathered}
$$

where, $\epsilon_{\mathrm{J}, \mathrm{t}}$ is the residual of equation $\mathrm{J}$ ( $\mathrm{J}$ is equal to R, IMPC, IMPG, or IMPINTR), $\mu_{\mathrm{Jt}}$ is the structural shocks of variable $\mathrm{J}$; and the $\gamma$ 's are parameters. This identification is consistent with the following: (1) remittances are the most exogenous variable; (2) imports of consumption goods are affected contemporaneously by remittances; (3) the import of capital goods is depends on remittances (the income source included on the model) and imports of consumer goods via the accelerator mechanism; (4) the decision about the importation of intermediate goods dependent on all the variables of the system. This arrangement of the residuals is equivalent to the Cholesky decomposition with the ordering of variables presented ${ }^{6}$.

Figures 2 and 3 show the total dynamic reaction of the capital and intermediate goods' imports to a positive one standard deviation shock on consumption ${ }^{7}$. The accumulated responses of capital goods' imports increase after the occurrence of the shocks. The accelerator effects may explain this finding. Also, it can be observed that the first four responses in this Figure are statistically different from zero at a $5 \%$ level.

On the other hand, the import of intermediate goods permanently decreases as a response to the analyzed shock. This is the opposite of what occurs during the dynamic import of capital goods. The resource constraint of the analyzed economies may account for this behavior. These findings are consistent with the aforementioned theoretical model.

The accumulated impulse-response functions of the three categories of import to onestandard-deviation impulses in remittances are shown in Figures 4, 5, and 6. There is a positive

\footnotetext{
${ }^{6}$ Switching the order of consumption and capital goods do not alter the results qualitatively.

${ }^{7}$ The consumption response to its own shocks was omitted to save space.
} 
HERNÁNDEZ, TOLEDO Remittances and Imports in Latin America

Figure 2: Accumulated Response of Capital Goods' Imports to Shocks in Consumption Goods' Imports

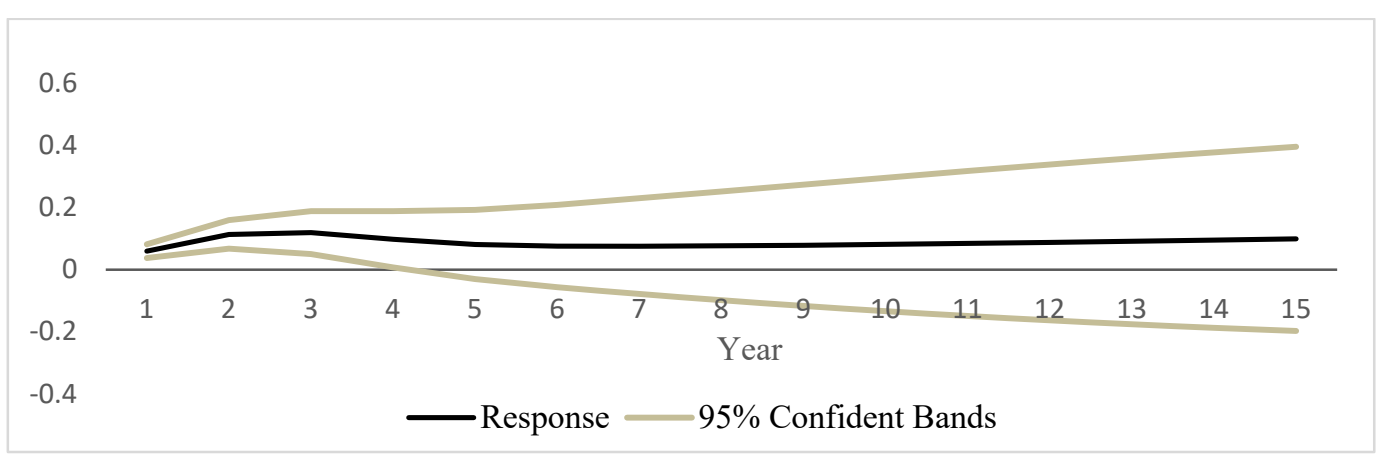

Figure 3: Accumulated Response of Intermediate Good's Imports to Shocks in Consumption Goods' Imports

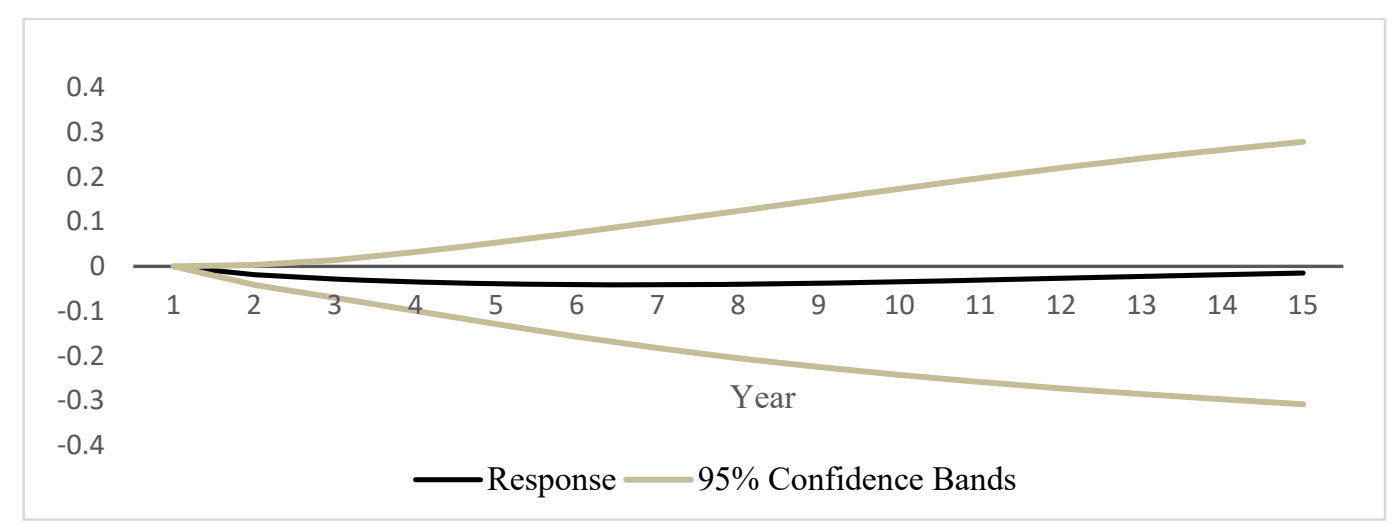

Figure 4: Accumulated Response of Capital's Imports to Shocks in Remittances

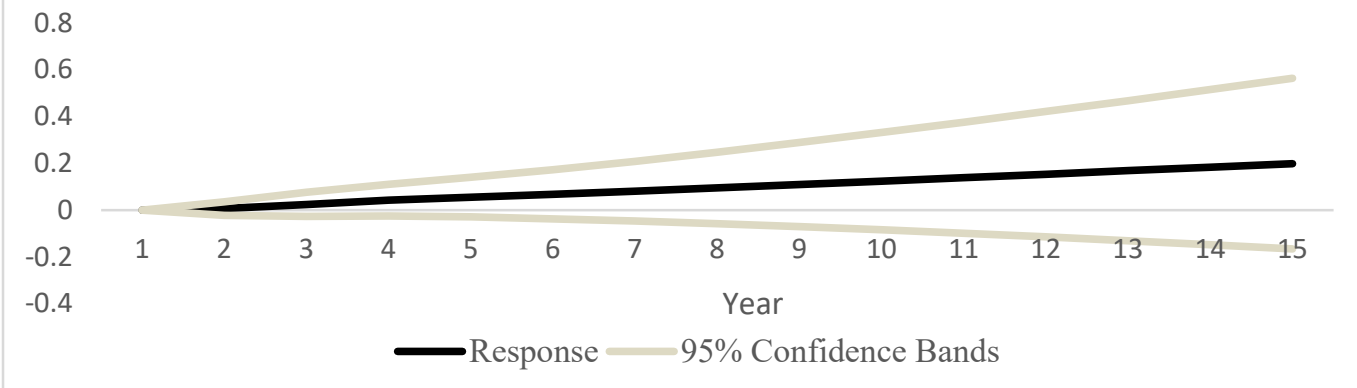


Figure 5: Accumulated Response of Consumption Goods' Imports to Shocks in Remittances

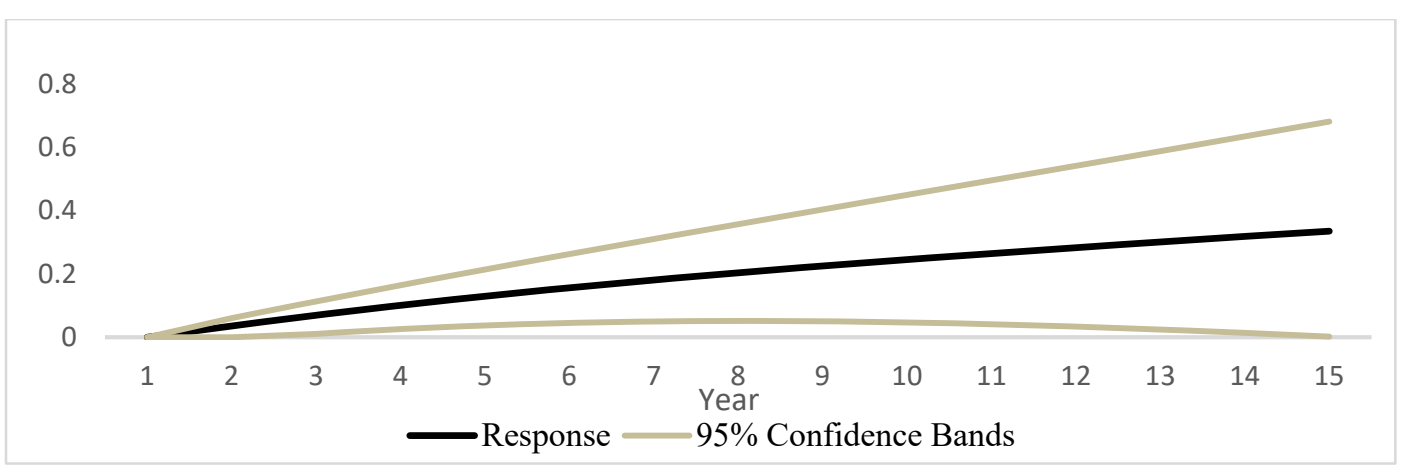

Figure 6: Accumulated Response of Intermediate Good's Imports to Shocks in Remittances

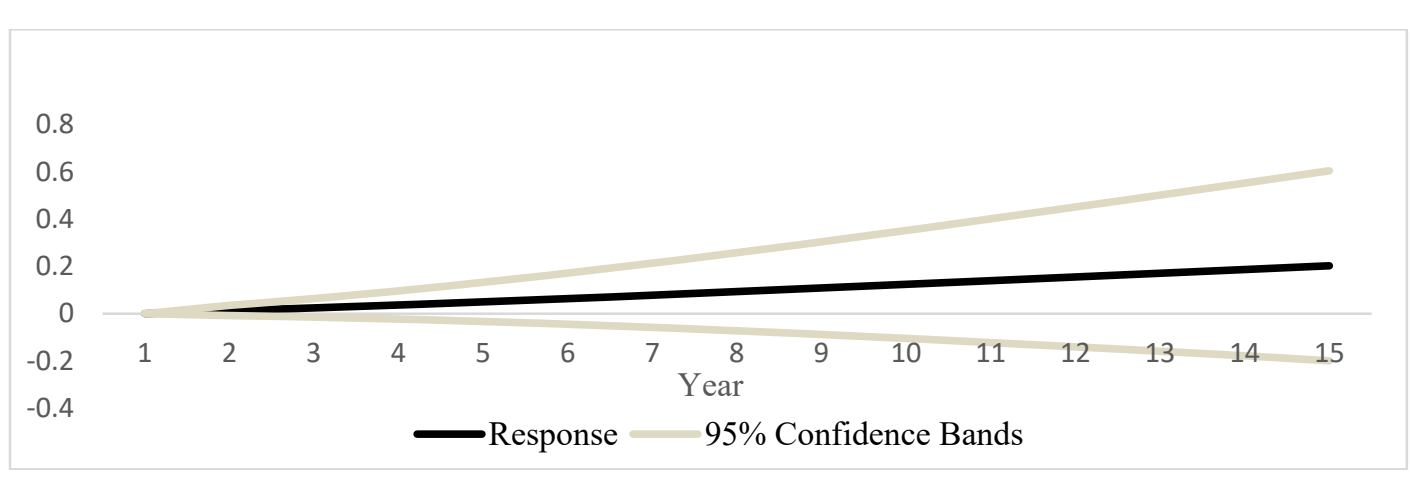

reaction from the three types of imports to this innovation. The imports of consumption goods exhibit a sharp increase as the initial response to these perturbations. Imports of intermediate goods mimic the behavior of consumption goods after the remittances' shocks. In the same manner, capital imports rise permanently as a consequence of the positive one-standarddeviation innovation in this type of income.

These findings are compatible with the aforementioned theoretical framework: Higher income has a positive, immediate, and persistent impact on consumption and capital responses later because of the accelerator mechanism. The results also suggest that increases in consumption and investment plans ultimately improve the state of the economy.

The proportions of the forecast error variance of the three import series attributable to innovations in remittances are presented in Table 4. This table suggests that in the short run, the remittances shocks explain a higher percentage of imports of consumption goods and intermediate goods error variance than imports of capital goods. 
HERNÁNDEZ, TOLEDO Remittances and Imports in Latin America

Table 4 Percentage of the Variance of Forecast Errors of the Variables in the Model Attributable to Shocks in Remittances

\begin{tabular}{|l||c|c|c|}
\hline \multirow{2}{*}{ Time Horizon } & \multicolumn{3}{|c|}{ Imports of: } \\
\cline { 2 - 4 } & Consumption Goods & Capital Goods & Intermediate Goods \\
\hline \hline 1 & 0.292 & 3.578 & 3.989 \\
\hline 2 & 10.120 & 3.736 & 10.833 \\
\hline 3 & 10.469 & 4.236 & 10.894 \\
\hline 10 & 10.260 & 16.165 & 21.664 \\
\hline
\end{tabular}

At a time horizon of three periods, remittances impulses account for $10.89 \%$ and $10.47 \%$ of imports of intermediate products and consumer goods, respectively. Conversely, at this forecast horizon, the percentage of the capital goods imports variance that can be attributed to this shock is only $4.24 \%$. At a longer prediction horizon, ten periods, the importance of remittances for capital dynamics is greater than for consumer goods imports. As stated in the investment accelerator theory, increases in consumption in each period stimulate capital investment in subsequent years. However, it is pertinent to point out that if we take the sum of intermediate goods and imports of final goods as the measure of consumption, then this motive seems to be more important for the migrant workers in this region than investment.

\section{Conclusions}

This is one of the few studies that evaluate the effect of remittances on the imports of different types of goods. This paper presents a plausible mechanism that explains how remittances affect economic development through the increase of capital imports. A panel VAR, using data from eight Latin American economies during the 1991 to 2004 period, was estimated. The estimations of the impulse response functions show that this type of income increases imports of capital, consumption, and intermediate goods. This result has some important implications for developing countries. First, it implies that some of the remittance income may go back to the developed countries. Second, this means that it is highly likely that the impact on capital occurs through consumption. This finding may be explained by the accelerator effect of sales on investment. Given the relevance of imports of capital and transfer of knowledge on development, this is a significant result for the countries in the analyzed geographical area.

Another implication of the estimation results is that through imports, remittances may also raise the exchange rate and reduce exports. Hence, this type of income may transform into a form of "Dutch Disease" by generating a loss of competitiveness in the tradable goods sector (Amuedo-Dorantes and Pozo, 2004). This situation, in turn, will impose a burden on domestic exporters and may have an adverse impact on economic growth. This is a line of research that we will pursue in the future. In subsequent research, it would also be interesting to build a 
dynamic stochastic general equilibrium model with a specific utility function. Such a model can be estimated or calibrated using a larger sample of countries to get more robust evidence on the impacts of remittances on imports.

\section{References}

Abel, A.B., and Blanchard O. (1986), Investment and Sales: Some Empirical Evidence, NBER Working Paper 2050.

Acosta, P., Calderón, C., Fajnzylber, P., and López, H. (2006), Remittances and Development in Latin America, The World Economy, 29, 957-987.

Adams, R. (2005), Remittances, Household Expenditure and Investment in Guatemala, World Bank Policy Research Working Paper 3532.

Adams, R. H., and Page J. (2005), Do international migration and remittance reduce poverty in developing countries? World Development, 33, 1645-1669.

Amuedo-Dorantes, C. and Pozo, S. (2004), Workers' Remittances and the Real Exchange Rate: A Paradox of Gifts, World Development, 32, 1407-1417.

Arize A., and Osang, T. (2007), Foreign Exchange Reserves and Import Demand: Evidence from Latin America, The World Economy, 30, 1477-1489.

Becker, Gary (1993), Human Capital. Chicago, IL: University of Chicago Press.

Buckley, P.J. and Casson, M.C. (1976), The Future of the Multinational Enterprise. London: Homes and Meier Press.

Byun, C. C. (2013), Habit Formation and U.S. Household Consumption: A Semiparametric Panel Data Analysis, Advances in Economics and Business 1, 222-232.

Castaldo, A. and Reilly, B. (2007), Do Migrant Remittances Affect the Consumption Patterns of Albanian Households?, South-Eastern Europe Journal of Economics, 1, 25-54.

Chami, R., Fullenkamp, C., and Jahjah, S. (2003), Are Immigrant Remittance Flows a Source of Capital for Development?, International Monetary Fund, Working Paper 03/189.

Dutta, D., and Ahmed N. (1999), An Aggregate Import Demand Function for Bangladesh: a Cointegration Approach, Applied Economics, 31, 465-472.

Eastwood, R., Kirsten, J., and Lipton, M. (2006), Premature Deagriculturalisation? Land Inequality and Rural Dependency in Limpopo Province, South Africa, Journal of Development Studies, 42, 1325-1349.

Edwards, A., and Ureta, M. (2003), International Migration, Remittances and Schooling: Evidence from El Salvador, Journal of Development Economics, 72, 429-461.

Fajnzylber, P. and Lopez J. (2007), Close to Home: the Development Impact of Remittances in Latin America., Word Bank Working Paper 48911.

Franko, P. (2007), The Puzzle of Latin American Economic Development. Lanham, MD: Rowman \& Littlefield Publishers. 
Hammill, M. (2007), Growth, Poverty and Inequality in Central America, United Nations, CEPAL-Serie Estudios y Perspectivas 88.

Head, K., and Ries, J. (2003), Heterogeneity and the FDI Versus Export Decision of Japanese Manufacturers, Journal of the Japanese and International Economies, 17, 448-467.

Jalana, J., and Ravallion, M. (2002), Geographic Poverty Traps? A Micro Model of Consumption Growth in Rural China, Journal of Applied Econometrics, 17, 329-346.

Khan, M., and Knight, M. (1988), Import Compression and Export Performance in Developing Countries, The Review of Economics and Statistics, 70, 315-321.

Lopez, H., Molina L., and Bussolo, M. (2007), Remittances and the real exchange rate, World Bank Policy Research Working Paper 4213.

Stark, O., Taylor J., and Yitzhaki S. (1986), Remittances and Inequality, The Economic Journal, 96, 722-740.

Suro, R., (2003), Remittance Senders and Receivers: Tracking the Transnational Channel, Washington, DC: Multilateral Investment Fund, Inter-American Development Bank, Pew Hispanic Center and Bendixen \& Associates.

Taylor, J. (1992), Remittances and Inequality Reconsidered: Direct, Indirect, and Intertemporal Effects, Journal of Policy Modeling, 14, 187-208.

Taylor, J., and Mora, J. (2006), Does Migration Reshape Expenditures in Rural Households? Evidence from Mexico, World Bank Policy Research Working Paper 3842. 